\title{
Physical Compatibility and Chemical Stability of Ketamine-Morphine Mixtures in Polypropylene Syringes
}

\author{
Ronald F Donnelly
}

\begin{abstract}
Background: Small amounts of ketamine administered with a narcotic can help to reduce both requirements for and potential adverse effects of the opioid. The use of ketamine in conjunction with morphine has become popular with the Acute Pain Service of the author's hospital. However, the only reported stability data that have been found for this combination stored in syringes were for 6 days at room temperature.
\end{abstract}

Objective: To conduct a compatibility and stability study with the ultimate aim of extending the current expiry date for the concentrations of ketamine and morphine combinations used at the author's institution and thus to allow batch production of mixtures of these drugs without increasing wastage.

Methods: Commercial solutions of ketamine $(50 \mathrm{mg} / \mathrm{mL})$ and morphine sulphate $(50 \mathrm{mg} / \mathrm{mL})$ were combined and further diluted with $0.9 \%$ sodium chloride to final concentrations of ketamine $2 \mathrm{mg} / \mathrm{mL}$ and morphine 2, 5, or $10 \mathrm{mg} / \mathrm{mL}$; the resulting mixtures were packaged in polypropylene syringes. The syringes were stored at either $23^{\circ} \mathrm{C}$ or $5^{\circ} \mathrm{C}$ for 91 days. The following physical compatibility parameters were monitored: clarity, colour, and $\mathrm{pH}$. Chemical stability was determined with a validated stability-indicating highperformance liquid chromatography system.

Results: Over the 91 days, all solutions remained clear and colourless, and the $\mathrm{pH}$ did not change significantly. The concentration of each drug in the various solutions remained above $98 \%$ of the original concentration for both storage conditions for the duration of the study.

Conclusions: Solutions of ketamine $(2 \mathrm{mg} / \mathrm{mL})$ combined with morphine $(2,5$, or $10 \mathrm{mg} / \mathrm{mL})$ were physically compatible and chemically stable for 91 days when diluted with normal saline, packaged in polypropylene syringes, and stored at either $23^{\circ} \mathrm{C}$ or $5^{\circ} \mathrm{C}$.

Key words: ketamine, morphine, admixture, syringe, stability, highperformance liquid chromatography

Can J Hosp Pharm 2009;62(1):28-33

\section{RÉSUMÉ}

Contexte : Ladministration de petites doses de kétamine avec un narcotique peut aider à réduire à la fois les besoins en opioïdes et leurs effets indésirables potentiels. L'emploi de kétamine en association avec de la morphine a gagné en popularité dans le Service de gestion de la douleur aiguë de l'hôpital de l'auteur. Cependant, les seules données publiées sur la stabilité de cette association conservée dans des seringues faisaient état d'une durée de six jours à la température ambiante.

Objectif : Mener une étude de compatibilité et de stabilité pour tenter de prolonger la durée de conservation actuelle des concentrations de kétamine et de morphine utilisées en association à l'hôpital de l'auteur et d'ainsi permettre la préparation par lots des mélanges sans en accroître le gaspillage.

Méthodes : Des solutions commerciales de kétamine $(50 \mathrm{mg} / \mathrm{mL})$ et de sulfate de morphine $(50 \mathrm{mg} / \mathrm{mL})$ ont été mélangées et diluées à nouveau dans du chlorure de sodium à $0,9 \%$ pour obtenir des concentrations finales de kétamine de $2 \mathrm{mg} / \mathrm{mL}$ et de morphine de 2,5 ou $10 \mathrm{mg} / \mathrm{mL}$; les mélanges ainsi obtenus ont été conditionnés dans des seringues de polypropylène. Les seringues ont été entreposées à $23^{\circ} \mathrm{C}$ ou à $5{ }^{\circ} \mathrm{C}$ pendant 91 jours. Les paramètres d'évaluation de la compatibilité physique étaient la limpidité, la couleur et le $\mathrm{pH}$. La stabilité chimique a été déterminée à l'aide d'une épreuve validée par chromatographie liquide haute performance.

Résultats : Toutes les solutions sont demeurées limpides et incolores et leur $\mathrm{pH}$ n'a pas changé significativement pendant la période de 91 jours. La concentration de chaque médicament des diverses solutions est demeurée supérieure à $98 \%$ de la concentration initiale aux deux températures d'entreposage pour la durée de l'étude.

Conclusions : Les solutions de kétamine $(2 \mathrm{mg} / \mathrm{mL})$ en association avec de la morphine $(2,5$ ou $10 \mathrm{mg} / \mathrm{mL})$ étaient physiquement compatibles et chimiquement stables pendant une période de 91 jours lorsqu'elles étaient diluées à nouveau dans du chlorure de sodium à $0,9 \%$ et conditionnées dans des seringues de polypropylène qui ont été conservées à $23{ }^{\circ} \mathrm{C}$ ou $5^{\circ} \mathrm{C}$.

Mots clés : kétamine, morphine, mélange, seringue, stabilité, chromatographie liquide haute performance

[Traduction par l'éditeur] 


\section{INTRODUCTION}

$\mathrm{K}$ etamine is an $N$-methyl-D-aspartate receptor antagonist; it also exhibits some binding to opioid $\mu$ and $\sigma$ receptors. Morphine is a highly potent opiate analgesic drug; its pharmacologic action occurs through direct interaction with the $\mu$ opioid receptors in the central nervous system. When used in conjunction with morphine, ketamine has a synergistic effect without causing an increase in the side effect profile.

Lau and others ${ }^{1}$ studied the effect of exposure to fluorescent light and $\mathrm{pH}$ adjustment on the stability of ketamine and morphine mixed together in normal saline. They reported that the combination was stable for $24 \mathrm{~h}$ when stored at $21^{\circ} \mathrm{C}$ with exposure to light. The mixture was also stable for $24 \mathrm{~h}$ when the $\mathrm{pH}$ was adjusted to 5.9 with sodium bicarbonate. Roy and Hildgren $^{2}$ studied admixtures of ketamine and morphine diluted with normal saline and packaged in syringes, PVC bags, and medication cassette reservoirs. The 2 drugs, each at concentrations of 1,10 , or $25 \mathrm{mg} / \mathrm{mL}$, were stable for 6 days when stored at room temperature. Schmid and others ${ }^{3}$ found that a mixture of ketamine $(1.33 \mathrm{mg} / \mathrm{mL})$ and morphine $(2.0 \mathrm{mg} / \mathrm{mL})$ was stable for 4 days at room temperature over the $\mathrm{pH}$ range 5.5 to 7.5 .

The use of ketamine in conjunction with morphine has become popular with the Acute Pain Service of the author's institution. However, the short expiry date of 6 days with storage at room temperature does not allow for batch production without an increase in wastage. Therefore, a compatibility and stability study was undertaken to try to extend the current expiry date for ketamine $(2 \mathrm{mg} / \mathrm{mL})$ and morphine $(2,5$, or 10 $\mathrm{mg} / \mathrm{mL}$ ) in normal saline in polypropylene syringes.

\section{METHODS}

\section{Preparation of Admixtures}

Admixtures of ketamine and morphine were prepared by combining enough ketamine hydrochloride $(50 \mathrm{mg} / \mathrm{mL}$; Sandoz Canada Inc, Boucherville, Quebec, lot 129290, expiry November 2007) and morphine sulphate $(50 \mathrm{mg} / \mathrm{mL}$; Sandoz Canada, lot 130307 , expiry July 2007) with sufficient $0.9 \%$ sodium chloride (normal saline [NS]) to make solutions with final ketamine concentration of $2 \mathrm{mg} / \mathrm{mL}$ and final morphine concentrations of 2,5 , or $10 \mathrm{mg} / \mathrm{mL}$.

\section{Sample Collection}

Portions of each solution $(30 \mathrm{~mL})$ were packaged in six 60-mL polypropylene syringes (Becton Dickinson and Company, Franklin Lakes, New Jersey), which were sealed with syringe caps. Samples $(5 \mathrm{~mL})$ were collected from each syringe into glass vials and frozen at $-70^{\circ} \mathrm{C}$ for analysis at a later date.
Three syringes of each mixture were stored at $23^{\circ} \mathrm{C}$ with exposure to light, and three were stored at $5^{\circ} \mathrm{C}$ with protection from light. On days 7, 14, 28, 56, and 91, additional samples were similarly collected and frozen.

\section{Physical Compatibility}

To check for precipitation, samples from each syringe were inspected with the aid of a $4 \times$ illuminated magnifying light against a black background. Colour change was visually monitored with a white background. A calibrated $\mathrm{pH}$ meter with a silver-silver chloride electrode (Accumet 25, Fisher Scientific, Nepean, Ontario) was used to measure the $\mathrm{pH}$ of samples on each study day.

\section{HPLC Assay Chromatographic System}

The assay method was a modified version of a previously published procedure. ${ }^{2}$ The main modification was a decrease in concentration of the organic component of the mobile phase from $43 \%$ to $25 \%$ acetonitrile; in addition, the final $\mathrm{pH}$ was adjusted to 5.0 instead of 3.0 with sodium hydroxide $5 \mathrm{~N}$ (Fisher Scientific, lot SC6135444, expiry May 2008). The final mobile phase was filtered through a $0.45-\mu \mathrm{m}$ nylon filter and degassed.

The mobile phase was pumped through a $5-\mu \mathrm{m} \mathrm{C} 18$ $4.6 \times 250 \mathrm{~mm}$ column (Luna ODS 18[2] column, Phenomenex Inc, Torrance, California, lot 410754) at a rate of $1.0 \mathrm{~mL} / \mathrm{min}$ using an isocratic delivery pump (model LC-10AS, Shimadzu Corporation, Kyoto, Japan). A photodiode array detector (model SPD-M6A, Shimadzu Corporation) was set at $270 \mathrm{~nm}$ to monitor the peaks of ketamine, morphine, and the internal standard. An autoinjector (model SIL-10AXL, Shimadzu Corporation) was used to inject the $50-\mu \mathrm{L}$ samples. Phenol (Fischer Scientific, $0.3 \mathrm{mg} / \mathrm{mL}$, lot 026530) was used as the internal standard.

\section{Assay Validation}

Forcibly degraded samples of ketamine and morphine were used to prove the specificity of the HPLC method. Three sets of solutions containing either ketamine or morphine $(5 \mathrm{mg} / \mathrm{mL}$ ) were prepared. In the first set of solutions, the $\mathrm{pH}$ was adjusted to about 1.8 with concentrated hydrochloric acid (BDH, Toronto, Ontario, lot 120834/78180). Sodium hydroxide $5 \mathrm{~N}$ was used to adjust the $\mathrm{pH}$ of the second set of solutions to about 12.2. For the third set of solutions, $1 \mathrm{~mL}$ $30 \%$ hydrogen peroxide (Fisher Scientific, lot 043211) was added to $9 \mathrm{~mL}$ of each stock solution. The acidic and alkaline solutions were incubated in a water bath (Isotemp model 202S, Fisher Scientific) set at $60^{\circ} \mathrm{C}$. The solutions containing hydrogen peroxide were kept at room temperature. All solutions were 
analyzed at time 0 and then at 1, 29, 53, 83, 151, 173, 198, 221 , and $245 \mathrm{~h}$ for interfering peaks.

The purity of all peaks was determined through the use of multiwavelength (270 and $254 \mathrm{~nm}$ ) and ultraviolet (UV) spectral analysis (200-350 nm). The UV spectra of the ketamine and morphine degradation peaks were compared with the reference material for each compound, and correlation coefficients were calculated for all comparisons.

Five replicate injections at 3 separate time points were used to assess intraday variations and to calculate the coefficient of variance $(\mathrm{CV})$ for each drug. Interday variation of the assay method was based on changes to the slopes, linear coefficients, and average areas from 5 separate days. The CV for each parameter was determined. The accuracy of the method was determined from 5 recovery samples for each drug. The lowest concentration that generated a detectable peak while still retaining a linear relationship was defined as the sensitivity of that assay. Least-squares regression analysis was used to assess the linearity of all standard curves.

\section{Stability Study}

On the day of analysis, the vials of test solution were allowed to thaw for a minimum of $2 \mathrm{~h}$; the samples were then further diluted either 1:10 (for samples containing $2 \mathrm{mg} / \mathrm{mL}$ of both ketamine and morphine) or 1:25 (for samples containing $2 \mathrm{mg} / \mathrm{mL}$ ketamine with $5 \mathrm{mg} / \mathrm{mL}$ morphine and those containing $2 \mathrm{mg} / \mathrm{mL}$ ketamine with $10 \mathrm{mg} / \mathrm{mL}$ morphine) after addition of the internal standard. Samples from each syringe were analyzed in duplicate (total $n=6)$. The admixtures were considered chemically stable if they retained $90 \%$ of the original concentrations (i.e., at time zero).

\section{RESULTS \\ Physical Compatibility}

After 91 days of storage at $23^{\circ} \mathrm{C}$ or $5^{\circ} \mathrm{C}$, there were no visible signs of particulate matter in any of the samples. Each solution remained colourless over the course of the study. The $\mathrm{pH}$ increased by only about 0.4 units over the 91 days; this change was considered insignificant.

\section{Chemical Stability Study Assay Validation}

Chromatograms of ketamine and morphine at time zero appear in Figures $1 \mathrm{~A}$ and 2A, respectively. Acidification and heating for $245 \mathrm{~h}$ resulted in a $7 \%$ decrease in the concentration of ketamine (Figure 1B) and a 10\% decrease in the concentration of morphine (Figure 2B). Alkaline conditions produced more dramatic changes in concentration, with reductions of $22 \%$ for ketamine (Figure 1C) and 28\% for morphine (Figure 2C), relative to starting concentrations, after $245 \mathrm{~h}$ of heating. Oxidation resulted in nearly $18 \%$ destruction of ketamine (Figure 1D) and 22\% destruction of morphine (Figure 2D). None of the degradation peaks interfered with the parent
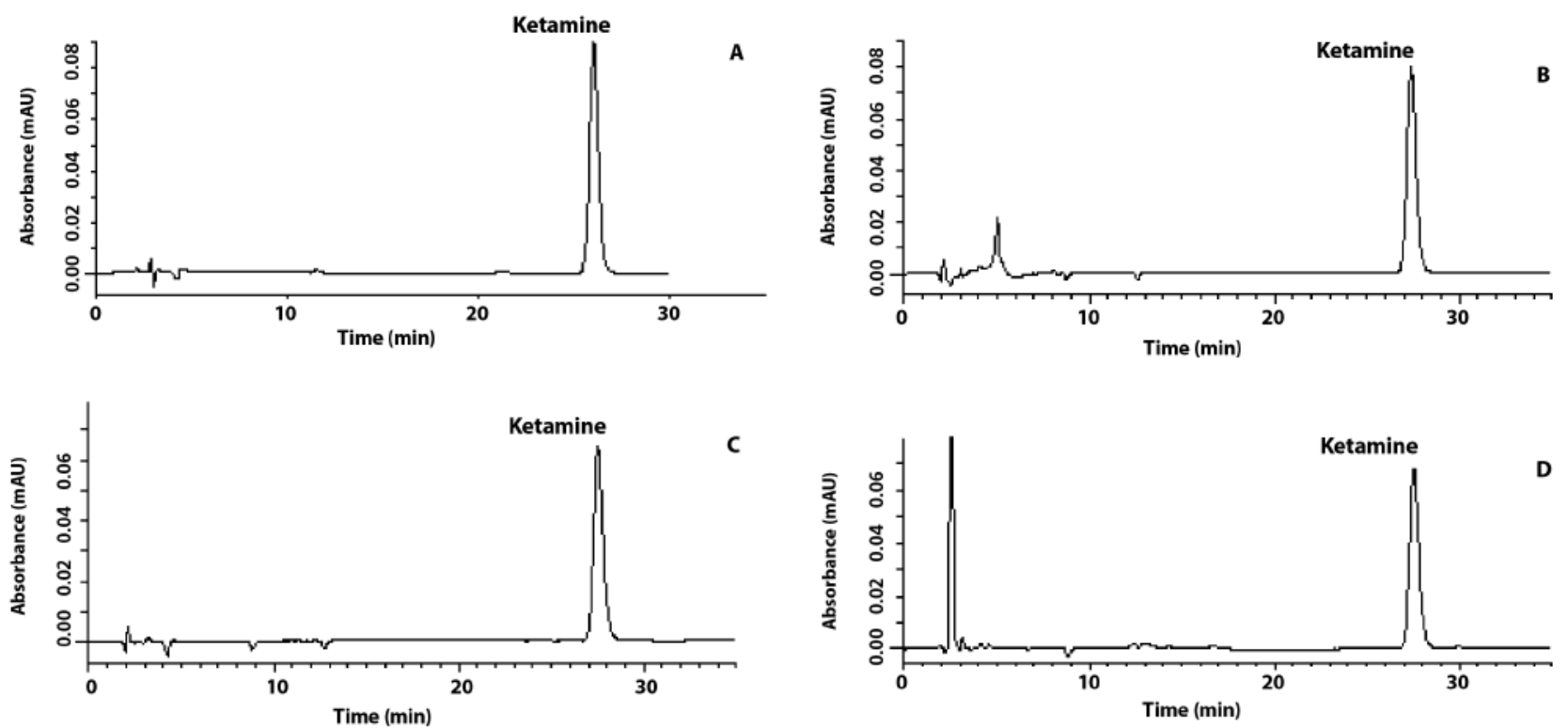

Figure 1. Sample chromatograms of ketamine and its degradation products. A: Fresh sample of ketamine at time zero. $\mathrm{B}$ : Acidified ketamine sample after heating at $60^{\circ} \mathrm{C}$ for $245 \mathrm{~h}$. C: Alkaline-degraded ketamine sample after heating at $60^{\circ} \mathrm{C}$ for $245 \mathrm{~h}$. D: Oxidized ketamine sample after $245 \mathrm{~h}$ at room temperature. 




A
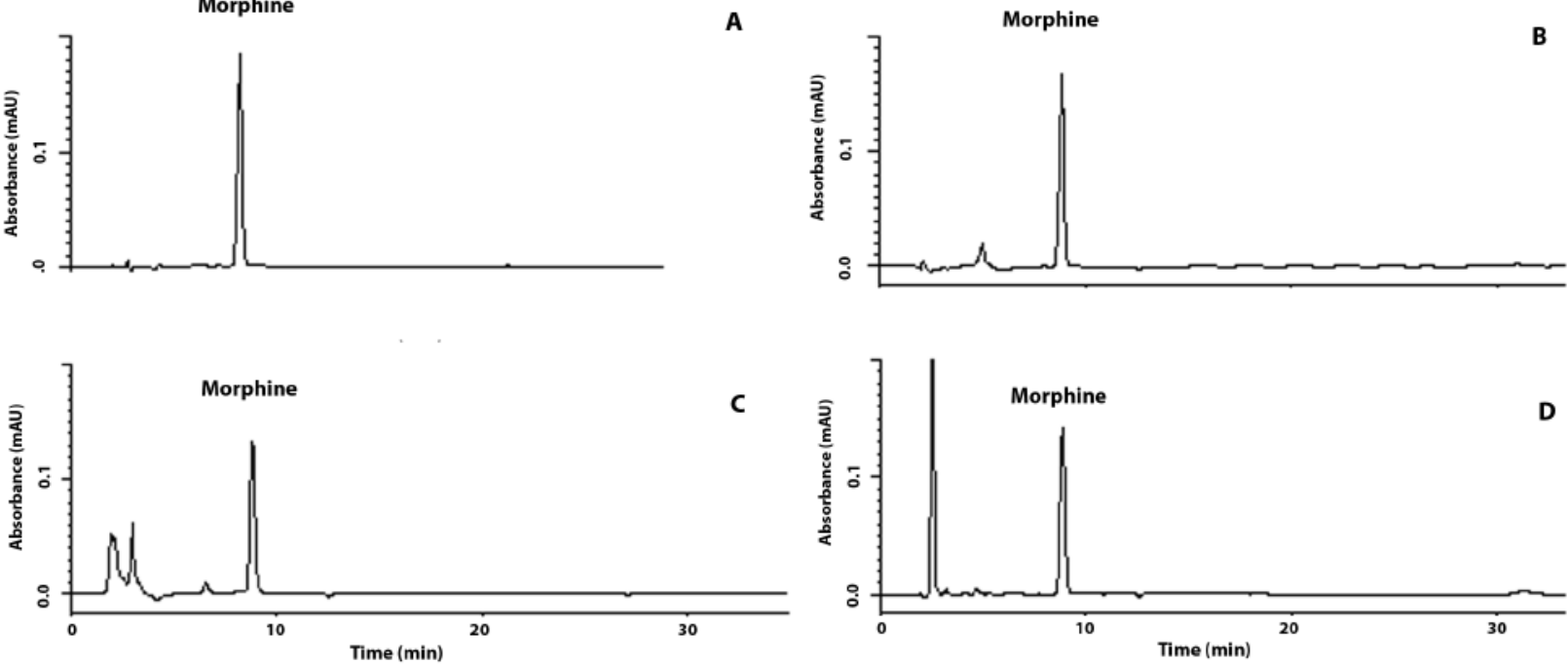

Figure 2. Sample chromatograms of morphine and its degradation products. A: Fresh sample of morphine at time zero. B: Acidified morphine sample after heating at $60^{\circ} \mathrm{C}$ for $245 \mathrm{~h}$. C: Alkaline-degraded morphine sample after heating at $60^{\circ} \mathrm{C}$ for 245 hours. D: Oxidized morphine sample after $245 \mathrm{~h}$ at room temperature.

compounds. The purity of all parent peaks in the degradation samples was confirmed by multichannel and UV spectral analysis. Spectral comparisons between the parent compounds and the reference material yielded good correlation (>0.990).

The intraday CV for the ketamine assay was $0.68 \%$, whereas the intraday variance for the morphine assay was $0.81 \%$ over $30 \mathrm{~h}$. When slopes, linear coefficients, and average areas from 5 separate days were compared, the CVs for interday testing were $1.82 \%, 0.06 \%$, and $1.27 \%$, respectively, for ketamine and $0.92 \%, 0.06 \%$, and $0.87 \%$, respectively, for morphine. The accuracy of the methods, as determined by a recovery study for each drug, was $99.7 \% \pm 1.02 \%$ for ketamine and $100.9 \% \pm 1.03 \%$ for morphine (means and standard deviations). The sensitivity of the ketamine and morphine assays was $620 \mathrm{ng}$ and $635 \mathrm{ng}$, respectively.

\section{Stability Study}

The results of the chemical stability study for the admixtures of ketamine and morphine are summarized in Tables 1 to 6. Neither the concentration of drug nor the storage conditions seemed to have a significant effect on the stability of either ketamine or morphine in these mixtures over the 91-day study period.

\section{DISCUSSION}

Roy and Hildgren ${ }^{2}$ studied the stability of admixtures of ketamine and morphine at concentrations of 1, 10, and $25 \mathrm{mg} / \mathrm{mL}$, packaged in PVC bags, syringes, and medication cassette reservoirs and found the combination to be stable for 6 days at room temperature. The current study extends the expiry date to 91 days for the combinations of ketamine and morphine most commonly used at the author's institution. The effects of storage at $5^{\circ} \mathrm{C}$ and of exposure to light were also determined. There was no apparent change in stability when syringes were stored at $5^{\circ} \mathrm{C}$ or when they were exposed to light. The variation in concentration of morphine did not seem to affect the compatibility or stability of the mixture.

At the $\mathrm{pH}$ values of the mixtures studied, ketamine and morphine exist predominantly in their cationic or ionized acid forms, according to the practically equal $\mathrm{pKa}$ values of 7.5 and 8.0, respectively. ${ }^{4}$ Thus, the lack of precipitation in the mixtures was expected. Similarly, oxidation of the phenolic hydroxyl group of morphine was not expected at the acidic $\mathrm{pH}$ values of the mixtures. ${ }^{5}$

Degradation products were adequately separated from the internal standard and from each of the parent compounds. Both ketamine and morphine were more stable under acidic conditions, whereas alkaline conditions caused more destruction of both drugs. The extent of degradation under harsh oxidative conditions suggested that both agents are somewhat sensitive to oxidation.

Admixtures of ketamine $(2 \mathrm{mg} / \mathrm{mL})$ and morphine $(2,5$, or $10 \mathrm{mg} / \mathrm{mL}$ ) were physically compatible and retained greater than $98 \%$ of their initial concentration after 91 days of storage at either $23^{\circ} \mathrm{C}$ with exposure to light or $5^{\circ} \mathrm{C}$ with protection from light when diluted with normal saline and packaged in polypropylene syringes. Verification of aseptic technique and 
Table 1. Stability of Mixture of Ketamine $(2 \mathrm{mg} / \mathrm{mL})$ and Morphine $(2 \mathrm{mg} / \mathrm{mL})$ in $0.9 \%$ Sodium Chloride Stored in Polypropylene Syringes at $23^{\circ} \mathrm{C}$

\begin{tabular}{|c|c|c|}
\hline \multirow[b]{2}{*}{ Storage Period } & \multicolumn{2}{|c|}{$\begin{array}{c}\% \text { of Initial Concentration Remaining* } \\
\text { (Mean } \pm \text { SD) } \dagger\end{array}$} \\
\hline & Ketamine & Morphine \\
\hline $\begin{array}{l}\text { Initial concentration } \\
(\mathrm{mg} / \mathrm{mL})\end{array}$ & $2.4 \pm 0.05$ & $2.1 \pm 0.04$ \\
\hline Day 7 & $100.2 \pm 1.4$ & $99.8 \pm 1.1$ \\
\hline Day 14 & $100.2 \pm 0.8$ & $99.6 \pm 0.6$ \\
\hline Day 28 & $100.3 \pm 1.7$ & $100.2 \pm 1.0$ \\
\hline Day 56 & $101.4 \pm 1.7$ & $100.2 \pm 0.7$ \\
\hline Day 91 & $99.7 \pm 1.2$ & $99.2 \pm 0.9$ \\
\hline
\end{tabular}

$\mathrm{SD}=$ standard deviation.

*Except where indicated otherwise.

tMean of 6 replications.

Table 3. Stability of Mixture of Ketamine $(2 \mathrm{mg} / \mathrm{mL})$ and Morphine $(5 \mathrm{mg} / \mathrm{mL})$ in $0.9 \%$ Sodium Chloride Stored in Polypropylene Syringes at $23^{\circ} \mathrm{C}$

$\%$ of Initial Concentration Remaining* $($ Mean \pm SD) $\dagger$

\begin{tabular}{lcc}
\cline { 2 - 3 } Storage Period & Ketamine & Morphine \\
\hline $\begin{array}{l}\text { Initial concentration } \\
(\mathrm{mg} / \mathrm{mL})\end{array}$ & $2.3 \pm 0.08$ & $5.0 \pm 0.03$ \\
Day 7 & $100.1 \pm 1.2$ & $100.1 \pm 1.3$ \\
Day 14 & $100.6 \pm 0.4$ & $99.3 \pm 0.5$ \\
Day 28 & $100.3 \pm 0.7$ & $99.5 \pm 0.6$ \\
Day 56 & $99.8 \pm 1.0$ & $99.6 \pm 1.1$ \\
Day 91 & $99.9 \pm 0.6$ & $98.4 \pm 0.4$ \\
\hline
\end{tabular}

$\mathrm{SD}=$ standard deviation.

*Except where indicated otherwise.

tMean of 6 replications.

Table 5. Stability of Mixture of Ketamine $(2 \mathrm{mg} / \mathrm{mL})$ and Morphine $(10 \mathrm{mg} / \mathrm{mL})$ in $0.9 \%$ Sodium Chloride Stored in Polypropylene Syringes at $23^{\circ} \mathrm{C}$

$\%$ of Initial Concentration Remaining* (Mean \pm SD) $\dagger$

\begin{tabular}{lcl} 
Storage Period & Ketamine & Morphine \\
\hline $\begin{array}{l}\text { Initial concentration } \\
(\mathrm{mg} / \mathrm{mL})\end{array}$ & $2.4 \pm 0.01$ & $10.2 \pm 0.03$ \\
Day 7 & $98.5 \pm 0.6$ & $99.0 \pm 0.5$ \\
Day 14 & $98.8 \pm 1.0$ & $99.0 \pm 0.5$ \\
Day 28 & $98.3 \pm 0.8$ & $98.7 \pm 0.4$ \\
Day 56 & $98.6 \pm 0.4$ & $98.6 \pm 0.4$ \\
Day 91 & $99.1 \pm 1.1$ & $98.4 \pm 0.6$ \\
\hline
\end{tabular}

$\mathrm{SD}=$ standard deviation.

*Except where indicated otherwise.

tMean of 6 replications.
Table 2. Stability of Mixture of Ketamine $(2 \mathrm{mg} / \mathrm{mL})$ and Morphine $(2 \mathrm{mg} / \mathrm{mL})$ in $0.9 \%$ Sodium Chloride Stored in Polypropylene Syringes at $5^{\circ} \mathrm{C}$

\begin{tabular}{|c|c|c|}
\hline \multirow[b]{2}{*}{ Storage Period } & \multicolumn{2}{|c|}{$\begin{array}{l}\% \text { of Initial Concentration Remaining* } \\
\text { (Mean } \pm \text { SD) } \dagger\end{array}$} \\
\hline & Ketamine & Morphine \\
\hline $\begin{array}{l}\text { Initial concentration } \\
(\mathrm{mg} / \mathrm{mL})\end{array}$ & $2.4 \pm 0.03$ & $2.0 \pm 0.01$ \\
\hline Day 7 & $100.1 \pm 1.5$ & $100.6 \pm 1.1$ \\
\hline Day 14 & $99.9 \pm 1.1$ & $100.4 \pm 0.9$ \\
\hline Day 28 & $98.9 \pm 1.0$ & $100.3 \pm 1.4$ \\
\hline Day 56 & $99.7 \pm 0.7$ & $100.4 \pm 0.6$ \\
\hline Day 91 & $99.1 \pm 1.3$ & $100.8 \pm 0.6$ \\
\hline
\end{tabular}

SD = standard deviation

*Except where indicated otherwise.

tMean of 6 replications.

Table 4. Stability of Mixture of Ketamine $(2 \mathrm{mg} / \mathrm{mL})$ and Morphine $(5 \mathrm{mg} / \mathrm{mL}$ ) in $0.9 \%$ Sodium Chloride Stored in Polypropylene Syringes at $5^{\circ} \mathrm{C}$

$\%$ of Initial Concentration Remaining* (Mean \pm SD)t

\begin{tabular}{lcc}
\cline { 2 - 3 } Storage Period & Ketamine & Morphine \\
\hline Initial concentration & & \\
$(\mathrm{mg} / \mathrm{mL})$ & $2.4 \pm 0.03$ & $5.1 \pm 0.03$ \\
Day 7 & $99.9 \pm 0.8$ & $100.7 \pm 1.4$ \\
Day 14 & $99.2 \pm 0.4$ & $99.9 \pm 0.7$ \\
Day 28 & $99.8 \pm 0.9$ & $99.9 \pm 0.4$ \\
Day 56 & $99.1 \pm 1.4$ & $99.6 \pm 0.3$ \\
Day 91 & $100.9 \pm 1.2$ & $100.3 \pm 0.6$
\end{tabular}

SD = standard deviation

*Except where indicated otherwise.

tMean of 6 replications.

Table 6. Stability of Mixture of Ketamine $(2 \mathrm{mg} / \mathrm{mL})$ and Morphine $(10 \mathrm{mg} / \mathrm{mL})$ in $0.9 \%$ Sodium Chloride Stored in Polypropylene Syringes at $5^{\circ} \mathrm{C}$

$\%$ of Initial Concentration Remaining* (Mean \pm SD) $\dagger$

\begin{tabular}{lrc} 
Storage Period & Ketamine & Morphine \\
\hline Initial concentration & & \\
$(\mathrm{mg} / \mathrm{mL})$ & $2.4 \pm 0.01$ & $10.2 \pm 0.09$ \\
Day 7 & $98.6 \pm 0.8$ & $100.0 \pm 1.7$ \\
Day 14 & $100.5 \pm 0.6$ & $101.3 \pm 0.4$ \\
Day 28 & $99.5 \pm 0.5$ & $101.0 \pm 0.3$ \\
Day 56 & $100.5 \pm 0.5$ & $101.5 \pm 0.5$ \\
Day 91 & $99.7 \pm 1.2$ & $100.0 \pm 1.0$
\end{tabular}

SD = standard deviation

*Except where indicated otherwise.

tMean of 6 replications. 
testing of sterility of finished products should be performed before this extended expiry date is implemented in practice.

\section{References}

1. Lau MH, Hackman C, Morgan DJ. Compatibility of ketamine and morphine injections. Pain 1998;75(2-3):389-390.

2. Roy JJ, Hildgen P. Stability of morphine-ketamine mixtures in $0.9 \%$ sodium chloride injection packaged in syringes, plastic bags and medication cassette reservoirs. Int J Pharm Compound 2000;4(3):225-228.

3. Schmid R, Koren G, Klein J, Katz J. The stability of a ketamine-morphine solution. Anesth Analg 2002;94(4):898-900.

4. Lemke TL, Williams DA, Roche VF, Zito SW. Foye's principles of medicinal chemistry. 6th ed. Baltimore (MD): Lippincott Williams \& Wilkins; 2008. p 1347, 1349.

5. Rosanske T. Morphine. In: Connors KA, Amidon GL, Stella VJ, editors. Chemical stability of pharmaceuticals: a handbook for pharmacists. 2nd ed. New York (NY): John Wiley \& Sons; 1986. p 604-611.
Ronald F Donnelly, MSc(Chem), BSc(Pharm), is the Product Development Pharmacist, Department of Pharmaceutical Services, The Ottawa Hospital (Civic Campus), Ottawa, Ontario.

Address correspondence to:

Ronald F Donnelly

Department of Pharmacy

The Ottawa Hospital

1053 Carling Avenue

Ottawa ON

K1Y 4E9

e-mail: rdonnelly@ottawahospital.on.ca 